\title{
ZAKAT DAN PAJAK DALAM PANDANGAN MASDAR FARID MAS'UDI
}

\author{
Tri Nurbayati
}

\section{Abstract}

Masdar Farid Mas'udi is intended to maintain the Islamic social construction by discussing zakat bistorically. He defined zakat as a tax concept which combined the two concepts from the government and Islam. He offered some concepts on interpreting that dualism.

Kata kunci: Zakat, Pajak, Ijtihad

\section{A. Pendahuluan}

Menurut mayoritas ulama, meskipun dalam redaksi yang berbeda-beda disimpulkan bahwa zakat merupakan bagian dari harta dengan persyaratan tertentu, di mana Allah SWT mewajibkan kepada pemiliknya untuk diserahkan kepada yang berhak menerimanya, dengan persyaratan tertentu pula. ${ }^{1}$ Zakat memiliki tujuan spiritual dan moral yang sangat tinggi, sebagaimana tercermin dalam firman Allah SWT QS. At-Taubah (9): 103 yang berbunyi:

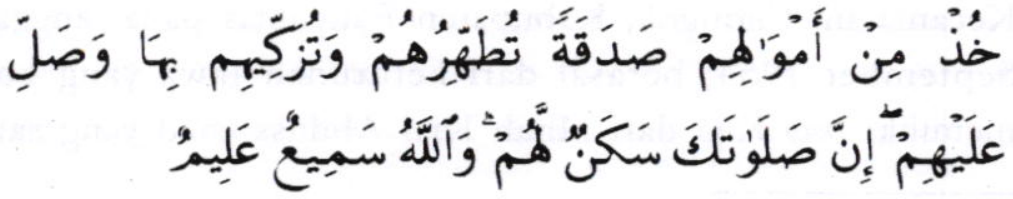

- Alumni STAIN Purwokerto Jurusan Syariah Program Studi Muamalah tahun 2009.

${ }^{1}$ Didin Hafidhuddin, Zakat dalam perekonomian Modern Jakarta: Gema Insani Press, 2002), hal 7. 
Konsep zakat berbeda dengan konsep pajak. Jika zakat merupakan kewajiban individu yang berdimensi spiritual maka pajak lebih berdimensi ketaatan politis. Pajak adalah merupakan kewajiban mengikat yang telah ditentukan oleh pemerintah atau pejabat yang berwenang, secara tunai harus dibayarkan dan tanpa adanya imbalan tertentu. ${ }^{2} \mathrm{Namun}$ demikian, ironisnya pajak sebagai sumber penerimaan Negara mengalami penguatan, sementara zakat mengalami kemunduran dan di anggap menjadi tanggungjawab pribadi masingmasing individu muslim.

Dalam pandangan Masdar Farid Mas'udi zakat dan pajak merupakan satu kewajiban. Jika zakat merupakan aspek spiritual dari perintah Allah SWT untuk menafkahkan harta secara baik dan benar, maka pajak merupakan upaya instusionalisasi perintah tersebut. ${ }^{3}$ Namun demikian proses transformasi lembaga pajak atau upeti ini digerakkan oleh Islam bukan dengan cara menyaingi atau menjajahi lembaga pajak dengan lembaga zakat, seperti dipersepsikan orang selama ini. Melainkan dengan cara memasukkan spirit ajaran zakat ke dalam lembaga pajak. Zakat sebagai ruhnya, pajak sebagai badannya, zakatnya sebagai komitmen spiritual moral, pajak sebagai wujud kelembagaan yang hendak menjadi ajang pengejawantahannya. Dalam bahasa syari'atnya, komitmen itu terjadi dengan cara meniatkan zakat dalam pembayaran pajaknya. ${ }^{4}$

\section{B. Biografi Singkat Masdar Farid Mas'udi}

Masdar Farid Mas'udi lahir di dusun Jombor, Desa Cipete, Kecamatan. Cilongok, Kabupaten Banyumas pada tanggal 18 September 1954, berasal dari keturunan Jawa yang konon memiliki trah Kiai dari Mbah Kiai Abdussomad yang sampai

\footnotetext{
${ }^{2}$ Anonim, Ensiklopedi Nasional (Jakarta: PT Cipta Adi Pustaka, 1999), XII: 31.

${ }^{3}$ Masdar Farid Mas'udi, Agama Keadilan: Risalah Zakat (Pajak) dalam Islam. Cet. 3 (Jakarta: P3M, 1993), hal. 97.

${ }^{4}$ Ibid, hal. 100.
} 
sekarangpun makam beliau masih selalu di ziarahi oleh masyarakat Islam Banyumas khususnya. ${ }^{5}$

Pendidikan formal Masdar diawali dari pendidikan dasar yang diselesaikannya di SD 01 Cipete Cilongok dalam waktu 5 tahun, kemudian setelah menamatkan SD Masdar dikirim ayahnya untuk melanjutkan pendidikan setingkat Tsanawiyah di Tegalrejo selama \pm 3 tahun. Selama di Tegalrejo, Masdar banyak belajar tentang agama Islam terutama dalam bidang ilmu alat, dengan mempelajari sekaligus menghafalkan nazam Alfiyah Ibnu 'Aqil. Setelah selesai dan lulus dari sekolah tersebut, Masdar kemudian hijrah ke Krapyak, Yogyakarta dan melanjutkan pendidikannya Madrasah Aliyah Krapyak. Tidak seperti siswa lain, Masdar berperan ganda sebagai guru sekaligus murid. Karena keahliannya dalam membaca kitab kuning sekaligus ilmu alatnya tersebut, Masdar dapat langsung menduduki kelas 3 sekaligus mengajar adik-adik kelasnya. ${ }^{6}$

Setelah menamatkan Aliyah, Masdar tetap tinggal di pesantren dan mengajar serta menjadi asisten pribadi Kiai Ali Maksum sebagai dosen luar biasa di IAIN Sunan Kalijaga. Baru pada tahun 1975, Masdar melanjutkan pendidikan di IAIN Sunan Kalijaga, Yogyakarta Fakultas Syari'ah Jurusan Tafsir Hadits dan selesai pada tahun 1979.

Setelah melalui berbagai pengalaman, Masdar melanjutkan program pasca sarjananya di Fakultas Filsafat Universitas Indonesia, Jakarta. Kemudian tidak jarang Masdar menjadi pembicara dalam berbagai seminar ilmiah mewakili sudut pandang Islam baik dalam ataupun luar negeri. Saat ini, Masdar menjadi Dosen Islamologi di STF Driyarkara, Jakarta. ${ }^{7}$

${ }^{5}$ Masdar Farid Mas'udi, "Jaringan Islam Emansipatoris: Humanis, Kritis, Transormatif, Praksis”, dalam wwnvislamemansipatoris.com, di-download pada tanggal 23 April 2008.

${ }^{6}$ Wawancara dengan Humam Mas'udi, Kakak kandung Masdar Farid Mas'udi, pada tanggal 27 Juni 2008.

7 Masdar Farid Mas'udi, “Jaringan Islam Emansipatoris: humanis, kritis, transormatif, praksis," dalam wnvislamemansipatoris.com, di-donnload pada tanggal 23 April 2008. 
Perjalanan karirnya di mulai ketika semangatnya berkobar sebagai aktivis Mahasiswa di IAIN Sunan Kalijaga. Pada tahun 1972, terpilih sebagai Ketua Pergerakan Mahasiswa Islam Indonesia (PMII) Komisariat Krapyak, Yogyakarta hingga tahun 1974. kemudian tahun 1976, terpilih sebagai Sekjen Dewan Mahasiswa IAIN Sunan Kalijaga. ${ }^{8}$ Kemudian sekitar tahun 1982, Masdar terpilih sebagai ketua I Pengurus Besar PMII periode 19821987 mendampingi Muhyidin Arubusman selaku Ketua Umum. Setelah menyelesaikan kuliah, tahun 1980 Masdar hijrah ke Jakarta. Oleh karena semasa kuliahnya Masdar seringkali menuliskan berbagai pemikiran kritisnya di media, maka pada saat itu Masdar bekerja di sebuah Lembaga Missi Islam NU dan menjadi wartawan di berbagai mass media ibu kota. ${ }^{9}$

Dengan di dukung oleh Rabithah Ma'ahid Islami (RMI) dibawah pimpinan (alm) KH. Imran Hamzah dan (alm) KH. Wahid Zaini, Masdar merintis berbagai kegiatan kajian khazanah keislaman salaf melalui berbagai halaqah. Di mulai dari halaqah Watucongkol tahun 1989, dengan tema "Memahami Kitab Kuning Secara Kontekstual”, kegiatan ini terus bergulir di berbagai daerah dengan keikutsertaan para kiai baik kiai sepuh ataupun kiai muda. Salah satu dari bentuk outputnya yang monumental adalah Rumusan Metode Pengambilan Hukum yang menjadi keputusan Munas NU Lampung 1992. ${ }^{10}$

Hingga saat ini, karir Masdar Farid Mas'udi tidak lepas dari komunitas Islam Nahdlatul 'Ulama (NU) yang berbasis pesantren, diantaranya; sebagai Ketua Pengurus Besar Nahdlatul 'Ulama (PBNU) sekaligus sebagai Direktur P3M Jakarta, Anggota Dewan Etik ICW (Indonesian Corruption Watch), Komisi Ombudsman Nasional (KON), serta membina sebuah pesantren Al-Bayan, di kampong Cikiwul, Pancoranmas, Cibadak,

${ }^{8}$ Ahmad Kosasi Marzukih, "Pancasila, Agama, dan Sistem Budaya," dalam wnvv.nu.orid, di-download pada tanggal 23 April 2008.

9 mvn.masdarmasudi.com, di-download pada tanggal 05 Mei 2008.

${ }^{10}$ Ibid. 
Sukabumi. Dalam komunitas NU sendiri, Masdar dikenal sebagai generasi muda kedua setelah Gus Dur yang pemikiran dan gerakannya memperoleh pengakuan dari kalangan dalam NU. Sebelumnya, keberadaan Masdar di LSM (dalam hal ini adalah P3M dan LAKPESDAM) semakin menjadikan pemikiranpemikirannya semakin progresif. Dalam konteks ini, tampaknya semakin berkembang kuantitas orang-orang NU yang terdidik di Perguruan Tinggi (termasuk Masdar didalamnya) yang juga telah mengalami proses interaksi dengan komunitas yang plural di perkotaan dengan ruang terbuka untuk mengembangkan aktivitas kritis melalui LSM. ${ }^{11}$

Pemikirannya yang terkenal dan paling diseriusi adalah konsep “Agama Keadilan”, terutama penafsirannya kembali atas ajaran zakat. Berawal dari problem ketidakadilan yang menyeluruh, yang diawali dari ketidakadilan ekonomi, Masdar berpendapat bahwa lebih dari sekedar ajaran sedekah, karitatif yang tidak berdampak, zakat pada dasarnya adalah konsep etika sosial dan politik kenegaraan untuk keadilan. Pada dataran teknis, zakat merupakan konsep perpajakan yang ada pada kewenangan negara/pemerintah untuk redistribusi pendapatan secara radikal agar kesejahteraan tidak hanya dapat dirasakan oleh golongan orang-orang kaya saja. ${ }^{12}$

\section{Penciptaan Agama Keadilan Berdasarkan Zakat dan Pajak}

Dalam sejarah Islam, zakat dan pajak pernah ditetapkan secara bersamaan. Dalam literatur fikih dan sejarah ditemukan istilah kharaj, jizyah dan 'usyr, ${ }^{13}$ Berbeda dengan zakat yang karena kedudukannya sebagai rukun Islam, maka dipandang sakral dan oleh sebab itu siapapun yang menanganinya dituntut sikap yang ekstra hati-hati, sedangkan kharaj, jizyah dan 'usyr tidak demikian.

${ }^{11}$ Laode Ida, NU Muda: Kaum Progresif dan Sekularisme Baru. Jakarta: Erlangga, 2004), hal 23.

${ }^{12}$ Marzukih, "Pancasila."

${ }^{13}$ Ali, Zakat Sebagai Instrumen, hal. 3. 
Secara eksplisit penyaluran dana zakat telah ditentukan dalam Al-Qur'an, sedangkan kharaj, jizyah dan 'usyr lebih memiliki ruang kebebasan dalam penyalurannya.

Dalam konteks Indonesia yang notabene berpenduduk mayoritas Islam namun bukan negara Islam, nilai keadilan yang dirasakan akan berbeda dengan nilai keadilan pada negara Islam ataupun negara sekuler. Karena tolok ukur masyarakat adil adalah suatu masyarakat yang bebas dari segala bentuk eksploitasi ekonomi dan dominasi budaya, agama, pengetahuan, ideologi, dan gender. ${ }^{14}$

Ada banyak cara ataupun pendapat untuk mewujudkan sebuah keadilan masyarakat dalam konteks kenegaraan. Berbagai contoh referensi pelaksanaan kebijakan dalam penentuan anggaran belanja negara, dari mulai zaman kepemimpinan Rasulullah SAW hingga pada masa sahabat serta kepemimpinan modern dapat dijadikan rujukan bagi penciptaan kesejahteraan negara, terutama menyangkut kemaslahatan penerapan ekonomi Islam dalam negara. Salah satu persoalan laten dalam konsep ekonomi Islam adalah persoalan dualisme zakat dan pajak yang harus ditunaikan warga negara Muslim. Hal ini telah mengandung perdebatan berlarut-larut hampir sepanjang sejarah Islam itu sendiri. Untuk itu, Masdar Farid Mas'udi menawarkan konsep untuk mengintegrasikan zakat dan pajak, sehingga kewajiban seorang muslim terhadap agama dan negara dapat terlaksana secara simultan. ${ }^{15}$

Masdar meyakini bahwa zakat adalah sebuah mekanisme spiritualisasi bermasyarakat melalui pintu masuk yang paling material. Sementara pintu masuk yang paling material dalam kehidupan berbangsa dan bernegara adalah pajak, karena tidak ada negara yang bisa hidup tanpa adanya pajak. Oleh karena itu,

${ }^{14}$ Mansour Fakih, "Fiqh Sebagai Paradigma Keadilan”,dalam Anang Haris Himawan (ed), Epistemologi Syara: Mencari Format Baru Figh Indonesia (Yogyakarta: Walisongo Press dan Pustaka Pelajar, 200), hal. 145.

${ }^{15}$ Ali, Zakat Sebagai Instrumen, hal. 57. 
Islam mensucikan kehidupan berbangsa, bermasyarakat dan berpolitik melalui zakat (pajak). ${ }^{16}$

Berdasarkan hal tersebut, Masdar Farid Mas'udi berpendapat bahwa ${ }^{17}$ :

Pemisahan lembaga zakat dan lembaga pajak adalah satu hal yang sesat dan menyesatkan. Karena konsep zakat adalah merupakan konsep pajak yang harus digunakan sebesar-besarnya untuk kemakmuran rakyat, tanpa memandang agama serta suku bangsa. Pada dasarnya, hakikat membayar pajak pada saat ini sama saja dengan membayar zakat, hanya saja tidak disadari. Oleh karena itu, setiap orang yang membayar pajak harus disertai dengan nilai membayar zakat kemudian setelah itu harus melakukan kontrol terhadap negara agar dana tersebut tidak diselewengkan.

Perbedaan antara yang niat dan yang tidak adalah menyangkut hak di akhirat nanti. Pembayaran pajak dengan niat zakat akan memperoleh pahala spiritual-uhrawi, karena dengan niat demikian itulah harapannya. Sedangkan yang tidak disertai niat maka ia tidak memperoleh hal tersebut. ${ }^{18}$ Sebagaimana dalam hadis: ${ }^{19}$

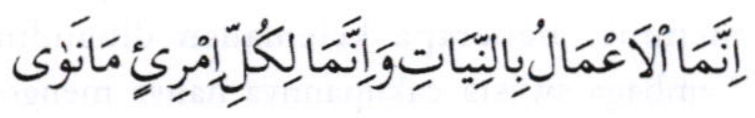

Niat adalah ruh, persambungannya adalah Tuhan. Sedang amal seperti sedekah/pajak adalah badan persambungannya dengan manusia. Keduanya berbeda, tetapi tidak untuk dipisahkan. Oleh karena itu, sebagaimana tercermin dalam konsep zakat, harta diserahkan kepada negara sebagai pelembagaan kepentingan manusia dalam mengatur kehidupannya. Sedangkan

${ }^{16}$ Masdar Farid Mas'udi, "Zakat Bukan Money Laundring” dalam Muhtar Sadili (ed), Problematika Zakat Kontemporer, (Jakarta: Forum Zakat (FOZ), 2003), hal. 172.

${ }^{17}$ Idem, "Zakat dan Keadilan Sosial," dalam Islam Pribumi, hal. 103.

${ }^{18}$ Ibid., hal. 104.

${ }^{19}$ Abū Dāwud, Sunan Abì Dänud (Beirut: Dār al-Fikr, 1994), I: 507. 
untuk Tuhan, cukup niat yang menjiwai dan melatarbelakangi penyerahan pajak itu saja. ${ }^{20}$

Setidaknya ada tiga hal yang berkaitan dengan pembayaran zakat dan pajak yang harus dilaksanakan oleh kaum muslim. Pertama, dalil-dalil yang membolehkan adanya kewajiban pajak di luar zakat. Kedua, syarat yang harus diperhatikan dalam kewajiban pajak. Ketiga, kritik terhadap tidak adanya ketentuan pajak di luar zakat. ${ }^{21}$

Sebagaimana disebutkan di depan, bahwa menurut Masdar Farid Mas'udi, zakat merupakan konsep perpajakan. Oleh karena itu, pihak yang dianggap mampu dan paling tepat sebagai amil, yakni dalam hal memungut, mengelola dan mendistribusikannya adalah negara atau pemerintah. ${ }^{22} \mathrm{Hal}$ ini dikarenakan $\mathrm{Nabi}$ Muhammad SAW telah menetapkan bahwa penunaian zakat (pajak) harus melalui pihak ketiga, yaitu amil yang secara struktural memiliki kewenangan politis untuk menegakkan kesejahteraan dan cita keadilan bersama. Pihak ketiga yang dimaksud adalah Imam atau pemerintah yang efektif dan memiliki komitmen pada kemaslahatan hidup warganya tanpa pilih kasih. ${ }^{23}$

Meskipun negara dinilai sebagai amil yang paling tepat, bukan berarti sebuah bentuk peniadaan terhadap lembagalembaga (BAZ dan LAZ) yang diistilahkan oleh Masdar dengan "lembaga swasta". Hanya saja, lembaga-lembaga swasta tersebut memiliki beberapa kelemahan dibanding lembaga negara. Lembaga swasta cakupannya hanya mengena pada pihak-pihak tertentu dan untuk hal-hal tertentu serta berkapasitas lokal, sementara negara cakupannya lebih menyeluruh. ${ }^{24}$ Dalam prakteknya, lembaga swasta dapat bertindak sebagai amil pembantu dengan syarat sebagai berikut: ${ }^{25}$

${ }^{20}$ Mas'udi, Agama Keadilan, hal. 149.

${ }^{21}$ Ali, Zakat Sebagai Instrumen, hal. 42.

22 Mas'udi, "Zakat dan Keadilan Sosial," hal. 101.

${ }^{23}$ Mas'udi, Agama Keadilan, hal. 124.

${ }^{24}$ Wawancara dengan Masdar Farid Mas'udi melalui telepon, pada tanggal 14 September 2008.

${ }^{25}$ Mas'udi, Agama Keadilan, hal. 146. 
Secara ideologis, lembaga/badan swasta tersebut bersifat terbuka dan berlaku adil terhadap siapapun tanpa memandang perbedaan apapun. Secara profesional mampu mengemban kepercayaan negara dalam hal ikut menegakkan keadilan dan memajukan kesejahteraan masyarakat. Secara formal, melalui persetujuan formal negara (yaitu badan legislatif negara sebagai penentu kolektif), berdasarkan pada syarat pertama dan kedua.

Selama ini, lembaga pengelola zakat kurang mendapatkan kepercayaan masyarakat. Hal ini menyebabkan sulitnya prospek lembaga pengelola zakat. Menurut Masdar, ada dua cara supaya aparat pelaksana menjadi bisa dipercaya, yaitu dengan pendekatan internal dan eksternal. Pendekatan internalnya adalah dengan melakukan penyadaran pada para pengelola keuangan publiks, bahwa uang negara/uang pajak adalah uang Allah, bukan uang penguasa. Jika ini berhasil, maka akan tercipta dorongan dari dalam untuk berlaku jujur dan hati-hati. Sementara pendekatan eksternal adalah dengan melakukan kontrol yang keras dari masyarakat untuk menciptakan pemerintahan yang bersih. ${ }^{26}$

Dengan demikian, titik temu untuk menghubungkan negara dan agama adalah terdapat pada penghargaan terhadap manusia dan kemanusiaan. Ideologi-ideologi sekular seperti liberalisme dan sosialisme sejatinya berusaha untuk menghargai manusia dan kemanusiaan dengan pendekatan yang berbeda. Begitu juga agama, yang juga membawa pesan untuk menyelamatkan manusia. Jika demikian halnya, maka konsep zakat sebagai sarana transformasi dan liberasi manusia seharusnya dapat diterima oleh ideologi-ideologi tersebut. Tentu saja tanpa harus menggunakan terminologi zakat, namun substansinya adalah upaya untuk mendistribusikan kekayaan kepada tujuan-tujuan kemanusiaan.

${ }^{26}$ Idem, "Zakat dan Keadilan Sosial", dalam Islam Pribumi, hal. 111-112. 


\section{Metode Penalaran Hukum Masdar Farid Mas'udi Terhadap Pengintegrasian Zakat dan Pajak}

Wacana fikih sebagai potret luar dari hukum Islam selama ini terlihat dingin dan kurang menunjukkan pemihakan (engagement) terhadap kepentingan masyarakat. Dalam pandangan Masdar, hal ini disebabkan karena adanya kelemahan paradigma, orientasi, prioritas dan perwatakan fikih itu sendiri. Oleh karena itu, watak ekslusif dalam fikih yang parsial (juz'iyyah), kasuistik dan micro oriented, formulasi fikih yang hanya berguna pasca kejadian, mengabaikan masalah-masalah strategis dan cenderung formalistik sehingga perlu dicarikan rumusan pengganti agar mampu menghadirkan kemaslahatan universal serta keadilan sosial. $^{27}$

Secara garis besar, pemikiran Masdar memiliki paradigma yang didominasi oleh pembahasan kemaslahatan-keadilan, demokrasi, hak asasi manusia yang muncul dari cita luhur agama Islam sebagai agama yang rabmatan lil'alamin. Dalam rangka pencapaian agama tersebut, melalui penyatuan zakat dan pajak, ada dua rumusan yang ditawarkan olehnya, yaitu:

1. Konsep Kemaslahatan Sosial

Dalam konteks kekinian, menurut Masdar segala bentuk tawaran teoritis baik didukung oleh nas ataupun tidak, maka segala bentuk yang menjamin kemaslahatan manusia adalah sah, dan umat Islam memiliki keterikatan untuk mengambil dan merealisasikannya. ${ }^{28}$

Masdar mengkritik keterikatan umat Islam yang berlebihan terhadap teks (nas), seperti yang dianut kaum ortodoks. Menurutnya sikap seperti ini akan membuat prinsip kemaslahatan hanya menjadi jargon kosong dan syari'ah yang pada mulanya berarti jalan telah menjadi tujuan bagi dirinya

${ }^{27}$ Fuad, Hukum Islam Indonesia, hal. 98

${ }^{28}$ Masdar Farid Mas'udi, "Konsep Pajak Mendeterminasi Akhlak Negara," Makalah tidak diterbitkan. 
sendiri. Bertolak dari pemikiran seperti ini, kaidah yang selama ini dipegang teguh para ulama, yakni idza șạ̣ḥa albadith fa buwa madzhabì, perlu ditinjau kembali karena ia lebih memperhatikan bunyi harfiah teks (nas) daripada kandungan substansinya. Menurut Masdar, kaidah ini lebih mengutamamakan ketentuan legal formal daripada tuntutan keadilan sebagai jiwanya. Sebagai konsekuensinya, kaidah tersebut bisa disubstitusi dengan kaidah yang berbunyi idzāa saḥhat al-maslahab fa buwa (biya) madzhabi ${ }^{29}$

Bentuk mudarat nyata atas pemisahan lembaga zakat dan pajak menurut Masdar adalah tidak adanya dispensasi pembayaran pajak atas umat Islam yang telah membayar zakat, meskipun sebagaimana tercantum dalam UU No. 38 tahun 2000 tentang pajak, zakat bisa sebagai pengurang pajak, tetap saja umat Islam diberi tanggung jawab ganda. ${ }^{30}$

2. Rekonstruksi Konsep Qat'ī -Zannī dalam Nas

Pada awalnya, al-Qur'an merupakan kalam Allah yang tidak berwujud nyata seperti suara ataupun tulisan. Dalam perkembangannya, al-Qur'an telah dibukukan dengan menggunakan bahasa Arab sebagai sarana komunikasi. AlQur'an berasal dari Allah SWT, namun dalam penggalian, makna dan pesan yang dikandungnya, perbedaan penangkapan seseorang terhadap arti yang terkandung dalam nas bukan merupakan hal yang mustahil.

Dalam perspektif fikih, ayat-ayat al-Qur'an dilihat dari penunjukan makna hukumnya dikategorikan menjadi dalil qat $\bar{i}$ dan dalil zanni, untuk lebih memperjelas wilayah ijtihad bagi para ulama. Pandangan umum mengenai ijtihad yang selama ini berjalan bisa dikatakan hanya menjangkau sasaran atau hal-hal yang bersifat zanni (teks yang tidak pasti) dan

\footnotetext{
${ }^{29}$ Idem, Agama Keadilan, hal. 110.

${ }^{30}$ Idem, "Konsep Pajak Mendeterminasi Akhlak Negara", makalah tidak
} diterbitkan. 
kurang mencermati dimensi ajaran yang diyakini sebagai nas qat $\bar{i}$ (teks yang dianggap pasti).$^{31}$

Menurut Masdar Farid Mas'udi, dalil qat 'i dalam hukum Islam sesuai dengan makna harfiyahnya adalah sebagai sesuatu yang bersifat pasti, tidak berubah-ubah dan bersifat fundamental. Sedang kategori zanni adalah seluruh ketentuan batang tubuh atau teks ketentuan normatif yang dimaksudkan sebagai upaya untuk menterjemahkan yang qat $i$ (nilai kemaslahatan dan keadilan) dalam kehidupan nyata. Namun demikian, ayat-ayat qat $t^{5} i$ bisa diijtihadi dalam rangka: ${ }^{32}$

a. Menemukan kerangka ontologis dari prinsip-prinsip yang dikandungnya

b. Untuk menemukan kerangka aksiologis, yakni mengenai cara, metode bagaimana prinsip-prinsip itu diaktualisasikan dalam proses sejarah yang terus berubah.

Secara eksplisit, rekonstruksi konsep qat' $\bar{i}-z a n n \bar{i}$ ini mengancam ketentuan formalitas teks. Kecenderungan yang begitu kuat dalam mengubah ketentuan-ketentuan yang bersifat teknis ini, dengan sendirinya akan menanggalkan banyak ketentuan legal-formal, karena dipandang tidak lagi sesuai kebutuhan. Dalam hal ini, Masdar menyatakan bahwa bagaimanapun, ketentuan legal-formal harus menjadi acuan tingkah laku masyarakat. Segala persoalan yang terjadi dalam kehidupan masyarakat harus ditundukkan pada ketentuan legal-formal yang berlaku dan sah. Akan tetapi, pada saat yang sama, hendaknya selalu disadari sedalam-dalamnya bahwa patokan formal/legal haruslah selalu tunduk pada cita kemaslahatan yang hidup dalam nurani masyarakat. ${ }^{33}$

Pemilihan yang diberikan Masdar antara yang qat $i i$ dan zanni $\bar{i}$ untuk menentukan kemaslahatan-keadilan sepertinya

\footnotetext{
${ }^{31}$ Fuad, Hukum Islam, hal. 100

${ }^{32}$ Mas'udi, Agama Keadilan, hal. 17.

${ }^{33}$ Ibid., hal. 134.
} 
lebih merupakan kreasi yang lahir dari teks itu sendiri, dan bukan dari luar teks yakni realitas dan konteks kesejarahan. Pasalnya, kreasi semacam itu bisa menjebak seseorang pada pencarian ayat-ayat yang dilihatnya sesuai dengan kepentingannya, kemudian dipatok sebagai ayat qat $i \bar{i}$ yang universal dan tidak berubah, sementara ayat-ayat lainnya yang dianggap tidak cocok dengan asumsinya dimasukkan dalam kategori zanni yang mudah berubah dan bersifat partikular, sehingga mudah dijatuhkan. ${ }^{34}$

Dalam penentuan suatu nas apakah termasuk qat $i$ atau zann $\bar{i}$ terjadi ketidakkonsistenan. Hal ini dapat dilihat dari ketidakjelasan dan ketidaksamaan klasifikasi nas qat $t^{j} i$ yang dibuat usuliyyun. Klasifikasi tersebut bersifat subyektif dan hukum yang dikandung bernilai relatif. Apabila dikaitkan dengan unsur historisitas yang melekat pada nas, maka nasnas yang secara subyektif diklaim sebagai nas qat ${ }^{5 i}$ dipengaruhi oleh sosio-kultural masyarakat pra-Islam dan masyarakat Arab itu sendiri. Artinya, ketentuan-ketentuan hukum yang diekspresikan Allah dan Rasul-Nya sangat dipengaruhi oleh kondisi setempat. ${ }^{35}$

Sebagai contoh konkret adalah mengenai obyek yang wajib dizakati. Masdar berpendapat bahwa cakupan harta yang harus dizakati (amwäl al-zakāb) harus diperluas untuk zaman sekarang, tidak adil jika kita hanya menggunakan pungutan sedekah wajib atas kurma dan anggur, sementara kelapa sawit, apel, kopi dan tembakau yang tidak kalah nilai ekonomisnya kita bebaskan begitu saja dari kewajiban zakat. atau juga ketika pendapat dari sektor pertanian wajib dikenakan zakat sementara sektor industri dan jasa dibebaskan. Penentuan obyek zakat pada masa Rasulullah

${ }^{34}$ Ahmad Baso, NU Studies: Pergolakan Pemikiran Antara Fundamentalisme Islam dan Fundamentalisme Neo Liberal (Jakarta: Erlangga, 2006), hal. 362.

${ }^{35}$ Ilyas Supena dan M. Fauzi, Dekonstruksi dan Rekonstruksi Hukum Islam (Yogyakarta: Gama Media, 2002), hal. 264. 
SAW tersebut dipengaruhi oleh kondisi sosial masyarakat pada saat itu. Jika suatu jenis kekayaan tertentu seperti industri dan sebagainya sudah ada pada zaman Rasulullah SAW, maka hal tersebut juga akan dikenakan zakat. ${ }^{36}$

Oleh karena itu, tidak perlu lagi memahami jenis barang yang wajib dikeluarkan zakatnya seperti disebut dalam nas, tetapi yang lebih penting adalah menangkap substansi kewajiban zakat, sehingga obyek wajib zakat bisa diperluas cakupannya, agar tercipta cita keadilan yang dicita-citakan bangsa.

\section{E. Implikasi Pengintegrasian zakat (Pajak) Terhadap Kelembagaan Zakat dan Pajak}

Dengan masuknya zakat dalam pajak ataupun bisa disebut dalam kebijakan fiskal negara maka akan mengakibatkan beberapa implikasi sosial- ekonomi terhadap kelembagaan zakat dan pajak Indonesia yang mencakup beberapa aspek:

1. Aspek Yuridis

Berkaitan dengan zakat sebagai satu pengaruh atas kewenangan negara terhadap pajak, terdapat UU Nomor 38 Tahun 1999 yang menyatakan bahwa pengelola zakat bukanlah lembaga resmi negara melainkan suatu badan atau lembaga yang khusus dibentuk dalam rangka menampung aspirasi teologis umat Islam, yaitu Badan Amil Zakat (BAZ) atau Lembaga Amil Zakat (LAZ). Keberadaan lembaga ini secara hukum tentu akan dapat menambah luasnya kewenangan daerah, dalam kebijakan fiskal ini, sebab Badan Amil Zakat pada umumnya berada di daerah-daerah, yang hingga saat ini telah mengumpulkan uang masyarakat dan kemudian didistribusikan kembali kepada masyarakat. ${ }^{37}$ Jika dikaitkan

${ }^{36}$ Fuad, Hukum Islam Indonesia, hal. 104.

${ }^{37}$ Edi Slamet Irianto dan Syarifuddin Jurdi, Politik Perpajakan: Membangun Demokerasi Negara (Yogyakarta: UII Press, 2005) hal. 105. 
dengan pemikiran Masdar untuk memberlakukan pajak dengan spirit zakat tersebut, maka secara otomatis harus ada perubahan secara mendasar mengenai UU tersebut.

2. Aspek Administratif Zakat dan Pajak

Menurut Masdar, jika pengelola zakat (pajak) adalah negara, maka hak atas penerimaan dan pengelolaan dana tersebut adalah orang-orang ataupun fungsi-fungsi yang terlibat dalam 4 bidang tanggung jawab sebagai berikut $:^{38}$

a. Pengontrol kebijakan zakat (pajak) sebagaimana di sepakati oleh rakyat wajib zakat (pajak).

b. Aparat pemungut/pencatat zakat (pajak).

c. Aparat administrasi perzakatan (perpajakan).

d. Segenap aparat departemen teknis yang bekerja untuk kesejahteraan (kemaslahatan) rakyat dengan dana zakat (pajak).

Hal ini berarti bahwa semua lembaga pengelola zakat berada di bawah naungan dan pengawasan negara, sementara lembaga negara tersebut berada di bawah kontrol sosial masyarakat yang kuat dengan alasan bahwa uang ataupun dana yang dikelola adalah milik Allah yang merupakan amanat dari rakyat bagi segenap rakyat (mustabiqqin). ${ }^{39}$

Sebagaimana disebutkan dalam QS. At Taubah: 60 maka para mustahik zakat adalah fakir, miskin, amil, muallaf, budak, ghärim (orang yang berhutang), sabilillah dan ibnu sabìl. Dengan demikian maka pada prinsipnya obyek dan besarnya nisăa yang telah dibakukan oleh para fukaha pada masa lalu tidak seharusnya menghalangi kita dalam merealisasikan cita kemaslahatan yang relevan dengan keadaan sekarang ini, terutama dalam hal penentuan obyek serta nisab zakat untuk

\footnotetext{
${ }^{38}$ Ibid., hal. 129.

39 Zainuddin Ali, Hukum Ekonomi Syariab (Jakarta: Sinar Grafika, 2008) hal. 116.
} 
diperluas dan diperbesar sesuai dengan pendapatan masyarakat masa kini. ${ }^{40}$

3. Aspek Pendistribusian Zakat dan Pajak

Penerimaan pajak dari tahun ke tahun meningkat, namun peningkatan tersebut tidak diikuti dengan penurunan angka kemiskinan. Seharusnya jika penerimaan pajak meningkat, maka angka kemiskinan harus menurun. Hal ini disebabkan karena jumlah dana yang dialokasikan untuk fakir miskin melalui Departemen Sosial hanya Rp 16,2 triliun atau 4,1\% dari APBN tahun 2005. Namun kemudian berdasarkan data tahun 2004, bahwa 51\% dari penerimaan pajak tahun 2004 digunakan untuk membayar cicilan hutang negara. ${ }^{41} \mathrm{Hal}$ ini menggambarkan belum terciptanya cita keadilan dalam distribusi kekayaan negara.

Menurut Masdar jika kemudian kita mengacu pada konsep zakat, maka tasaruf atau pendistribusian yang diwujudkan dalam APBN untuk sektor fakir miskin sekurang-kurangnya harus mendapatkan $25 \%$ baik dari APBN di tingkat nasional maupun APBD di tingkat daerah. ${ }^{42}$

4. Aspek Pentarifan zakat dan Pajak

Dalam teori perpajakan, ada 4 macam tarif yang dapat digunakan, yaitu : ${ }^{43}$

a. Tarif sebanding (proporsional), yakni berupa prosentase yang tetap terhadap berapapun jumlah yang di kenai pajak, sehingga besarnya pajak proporsional terhadap nilai yang dikenal pajak.

b. Tarif tetap, yaitu berupa jumlah yang tetap (sama) terhadap berapapun jumlah yang dikenai pajak sehingga besarnya pajak tetap.

${ }^{40}$ Lihat Mas'udi, Agama Keadilan, hal. 117-119.

${ }^{41}$ Gusfahmi, Pajak, hal .8-10.

${ }^{42}$ Mas'udi, "Zakat dan Keadilan Sosial" dalam Sayed Mahdi (ed), Islam Pribumi, hal. 108.

${ }^{43}$ Lihat Mardiasmo, Perpajakan, hal. 9. 
c. Tarif progresif, yaitu persentase tarif yang digunakan semakin besar jika jumlah yang dikenai pajak semakin besar.

d. Tarif degresif, yaitu persentase tarif yang digunakan semakin kecil bila jumlah yang dikenai pajak semakin besar.

Sedangkan dalam zakat hanya dikenal dengan menggunakan persentase tetap, meskipun kekayaan yang dikeluarkan zakatnya semakin besar. Untuk uang misalnya, persentase zakatnya $2,5 \%$ baik bagi yang memiliki uang mencapai nisab ataupun yang memiiki seribu kali nisab.

\section{F. Penutup}

Secara keseluruhan, usaha Pemerintah dalam menengahi permasalahan dualisme zakat dan pajak, terkait dengan adanya pemikiran Masdar Farid Mas'udi tersebut, yakni dengan adanya regulasi zakat sebagai pengurang penghasilan sebagaimana disebutkan dalam UU No. 38 tahun 1999 serta UU No. 17 tahun 2000 tentang pajak penghasilan masih kurang efektif, karena zakat hanya diakui sebagai biaya, maka dampak bagi kewajiban pajak masih relatif kecil, karena pada dasarnya esensi zakat dan pajak adalah berbeda. Jika zakat dapat mengurangi kewajiban pajak, maka mungkin akan sedikit lebih efektif karena lebih meringankan wajib pajak Muslim. Dengan demikian maka peningkatan zakat akan seiring dengan peningkatan pajak. Artinya ketika zakat mengurangi pajak, maka penerimaan zakat dan pajak justru meningkat.

Secara garis besar pemikiran Masdar dapat diidentifikasikan dalam sebuah kerangka paradigmatik yang disebutnya sebagai Islam pembebasan dan emansipatoris atau al-Isla $>m$ al-tab $\}$ arruri $>$. Masdar sangat tidak setuju dengan adanya taklid buta dalam beragama. Dalam hal ini Masdar terus menganjurkan agar aktivitas ijtihad harus terus dikembangkan sebagai upaya untuk mencari 
pilihan-pilihan konsepsional yang as $\{l a b\}$ bagi kehidupan umat manusia, berdasarkan asas kemaslahatan dan keadilan semesta dengan tanpa memandang perbedaan ras, keyakinan, agama, suku dan bahasa. Beberapa implementasi gagasan yang muncul dari pikiran Masdar Farid Mas'udi, secara paradigmatik memang berdasarkan atas kepedulian mendalam terhadap problemproblem kemanusiaan umat Islam khususnya yang berbasis pada kemaslahatan. 


\section{DAFTAR PUSTAKA}

Ali, Zainuddin. Hukum Ekonomi Syariah. Jakarta: Sinar Grafika, 2008.

Baso, Ahmad. NU Studies: Pergolakan Pemikiran Antara Fundamentalisme Islam dan Fundamentalisme Neo Liberal. Jakarta: Erlangga, 2006.

Dawud, Abu. Sunan Abi Dawud. Beirut: Daarul Fikr, 1994.

Fakih, Mansour. "Fiqh Sebagai Paradigma Keadilan,"dalam Anang Haris Himawan (ed.), Epistemologi Syara: Mencari Format Baru Figh Indonesia. Yogyakarta: Walisongo Press dan Pustaka Pelajar, 2000.

Hafidhuddin, Didin. Zakat dalam perekonomian Modern. Jakarta: Gema Insani Press, 2002.

Ida, Laode. NU Muda: Kaum Progresif dan Sekularisme Baru. Jakarta: Erlangga, 2004.

Irianto, Edi Slamet dan Jurdi, Syarifuddin. Politik Perpajakan: Membangun Demokrasi Negara. Yogyakarta: UII Press, 2005.

Marzukih, Ahmad Kosasih. "Pancasila, Agama, dan Sistem Budaya." Dalam www.nu.or.id, di-download pada tanggal 23 April 2008.

Mas'udi, Masdar Farid. "Jaringan Islam Emansipatoris: Humanis, Kritis, Transormatif, Praksis." Dalam www.islameman sipatoris.com, di-download pada tanggal 23 April 2008. 
. "Zakat Bukan Money Laundring” dalam Muhtar Sadili (ed.), Problematika Zakat Kontemporer. Jakarta: Forum Zakat (FOZ), 2003.

Agama Keadilan: Risalab Zakat (Pajak) dalam Islam. Jakarta: P3M, 1993.

Supena, Ilyas dan M. Fauzi. Dekonstruksi dan Rekonstruksi Hukum Islam. Yogyakarta: Gama Media, 2002.

Tim Penyusun. Ensiklopedi Nasional. Jakarta: PT Cipta Adi Pustaka, 1999.

www.masdarmasudi.com, di-download pada tanggal 05 Mei 2008.

Wawancara dengan Humam Mas'udi, Kakak kandung Masdar Farid Mas'udi, pada tanggal 27 Juni 2008.

Wawancara dengan Masdar Farid Mas'udi melalui telepon, pada tanggal 14 September 2008. 